\title{
EFFECT OF THE USE OF THERMAL WATER ON SKIN CELLS - AN IN VITRO STUDY
}

O Efeito Do Uso Da Água Termal Em Células Da Pele - Um Estudo In Vitro http://dx.doi.org/10.21116/2018.1

GODOY, Karolina de Melo Silva

Centro Universitário Jaguariúna - UniFAJ

SANCHES, Vitor Lacerda

Universidade de Campinas - Unicamp

PEIXOTO, Rafaella Regina Alves

Universidade de Campinas - Unicamp

CADORE, Solange

Universidade de Campinas - Unicamp

INACIO, Rodrigo Fabrizzio

Universidade de Campinas - Unicamp/ Faculdade Jaguariúna

\begin{abstract}
Nowadays, thermal water benefits for the health of skin cells has been widely broadcasting and its use is recommended for therapeutic and esthetic purposes. In this work, the study of the effect of thermal water was conducted in cultures of fibroblastic cells (Vero E6), a type of cells found in the dermis layer and essential components of the skin. The cells were cultivated using thermal, deionized (ultrapure) and tap water. A growth cell curve for each condition was made to compare which type of water promotes a higher growth rate. Cells cultivated with thermal water exhibited a higher and similar growth rate than cells cultivated with deionized water with 48 and 76 hours of culture, respectively. The mineral contents of the three types of water, culture mediums and cells were also studied. The mineral content analysis showed that thermal water contains significant amounts of $\mathrm{Ca}, \mathrm{Na}$ and $\mathrm{Mg}$, but the higher contents found do not enhanced the uptake of these elements by the cells.
\end{abstract}

Keywords: thermal water, skin, fibroblast, cell culture, Vero E6 cells, mineral content.

RESUMO: Hoje em dia, os benefícios da água termal para a saúde das células da pele têm sido amplamente difundidos e seu uso é recomendado para fins terapêuticos e estéticos. Neste trabalho, o estudo dos efeitos da água thermal foi conduzido em culturas de células de fibroblastos (Vero E6), um tipo de células encontradas na camada da derme e é um componente essencial da pele. As células foram cultivadas usando água thermal, deionizada (ultra pura) e de torneira. Foi feita uma curva de crescimento de células para cada condição, para comparar qual tipo de água promove uma maior taxa de crescimento As células cultivadas com água termal exibiram uma taxa de crescimento superior e semelhante à das células cultivadas com água deionizada com 48 e 76 horas de cultura, respectivamente. Também foram 
estudados os teores minerais dos três tipos de água, meios de cultura e células. A análise de conteúdo mineral mostrou que a água termal contém quantidades significativas de $\mathrm{Ca}, \mathrm{Na}$ e $\mathrm{Mg}$, mas os maiores teores encontrados não aumentam a captação destes elementos pelas células.

Palavras chave: água termal, pele, fibroblastos, cultura de células, células Vero E6, conteúdo mineral.

\section{INTRODUCTION}

Thermal water is widely known by its therapeutic properties, which nowadays is recognized by several areas of medical intervention (FAÍLDE, MOSQUEIRA, 2006). Its use begins to appear in the nineteenth century, when this type of water was still designated as "mineral water" (NOCCO, 2008). Currently, the term "thermal water" substituted the term "medicinal mineral water" (TEIXEIRA, 2007) and can be defined as a type of water originated in the deep layers of the soil that emerges from depths, crossing a geological layer composed mainly by calcium and magnesium carbonate (dolomite) (SUMMA, TATEO, 1998). The water can be cold (less than $20^{\circ} \mathrm{C}$ or $\left.68^{\circ} \mathrm{F}\right)$, warm $\left(20^{-30^{\circ} \mathrm{C}}\right.$ or $86^{\circ} \mathrm{F}$ ) or hot (up to $100^{\circ} \mathrm{C}$ or $212^{\circ} \mathrm{F}$ ) (SEITE, 2013).

Each type of thermal water has particular physical-chemical characteristics that will indicate their therapeutic functions in prophylactically, curative or rehabilitation treatments (TEIXEIRA, 2007, GHERSETICH et al., 2001; GOMES, SILVA, 2007). Some of these main characteristics are their origin, bacteriological purity, therapeutic potential (LOTTI, GHERSETICH, 1996) and chemical composition.

According to several bibliographical sources, thermal water can act as moisturizing (ELKHYAT et al., 2004; RAWLINGS, HARDING, 2004), presents anti-irritant, anti-pruritic, anti-inflammatory, immunomodulatory and skin-repairer barriers properties (FAÍLDE, MOSQUEIRA, 2006; PRISTA, BAHIA, VILAR, 1992; WILHELM, FREITAG, WOLFF, 1994; SALMON, ARMSTRONG, ANSEL, 1994; HALEVY, SUKENIK, 1998; MATZ, ORION, WOLF, 2003; BOCK, SCHURER, SCHWANITZ, 2004; YURTKURAN et al., 2006). It can also aid on the control of the $\mathrm{pH}$ of the skin (WILLIAMS et al., 2007) and acts as analgesic and in the circulatory system (MATZ, ORION, WOLF, 2003; ROQUES, DE BOISSEZON, QUENEAU, 2009; POENSIN et al., 2003), besides of their 
antioxidant properties (GOMES, SILVA, 2007; VILE, TYRRELL, 1995; HALLIDAY et al., 2008).

All these properties would contribute to a better health of the skin. The cutaneous effects of the topic application of water are possibly related to the local interaction between thermal water essential components and the skin structure (FAÍLDE, MOSQUEIRA, 2006). It is also important to mention that water is the most important substance present in the skin (BARATA, 2002; CUNHA, SILVA ROQUE, CUNHA, 2004), representing about $60 \%$ of the body weight of an adult (BERNSTEIN et al., 1996). In this way, the chemical and thermal properties of water could have a significant impact on cell physiology (MATZ, ORION, WOLF, 2003).

The rich mineral composition of thermal water, which generally presents high levels of essential elements such as sodium, magnesium, zinc, boron and manganese, has been pointed out as one of the main reasons for its beneficial effects for the skin (CHEBASSIER et al., 2004; NAKAGAWA et al., 2004). These elements are part of the mineral composition of the rocks, whereby the water emerges from the surface.

Experimental studies demonstrated that these elements present in thermal water stimulate the migration of keratinocytes, contributing for skin cell renewal (CHEBASSIER et al., 2004). For this reason, the use of thermal water in natura or as a part of manipulated products is dermatologically indicated as adjunct to act on skin hydration, cutaneous aging, acne, rosacea and other inflammatory skin processes. Its use is also recommended after chemical peelings, lasers and other skin treatments that may irritate the skin or cause a change in the electrolyte balance (HASHIZUME, 2004; DRAELOS, ERTEL, BERGE, 2006; LAQUIEZE, CZERNIELEWSKI, BALTAS, 2007).

Despite of the wide broadcasting of the possible beneficial effects associated with the use of thermal water, studies about these effects at a cellular level are still rare in the literature. The aim of this study was to investigate the possible beneficial effects of the use of thermal water in cultures of fibroblastic cells, one of the main types of cells of the skin tissue. The effect of the use of thermal water was compared with deionized (ultrapure water) and tap water with relation to the growth rate of the cells and their mineral composition. 


\section{MATERIALS AND METHODS}

\section{Materials, reagents and samples}

In this study, three types of water were evaluated: thermal, deionized and tap. Thermal water was obtained from Lindoya (Lindoya Verão ${ }^{\circledR}$, Lindóia, São Paulo, Brazil), deionized water was produced using a Milli-Q system (MILLIPORE, BEDFORD, MA) with a conductivity of $18.2 \mathrm{~m} \Omega \mathrm{cm}$, and potable tap water was collected from a faucet at the Chemistry Institute at the University of Campinas, Campinas, SP, Brazil.

For the chemical analysis, standard solutions of $\mathrm{Al}, \mathrm{Ba}, \mathrm{Cr}, \mathrm{Co}, \mathrm{Cu}, \mathrm{Fe}$, $\mathrm{Mg}, \mathrm{Mn}, \mathrm{Mo}, \mathrm{Ni}, \mathrm{P}, \mathrm{Pb}$ and $\mathrm{Zn}(1000 \mathrm{mg} / \mathrm{L})$ purchased from Sigma Aldrich (TraceCERT $^{\circledR}$, FlukaAnalytica, St. Louis, USA) and Tritisol $^{\circledR}$ concentrated $^{\circ}$ standards of $\mathrm{Ca}, \mathrm{K}$ and $\mathrm{Na}$, purchased from Merck Millipore (Darmstadt, Germany), were used for the preparation of the calibration standards for elemental determination. Nitric acid (65\%, w/w) and hydrogen peroxide $(30 \%$, w/w) were also purchased from Merck (Darmstadt, Germany). All the glassware and plastic materials used in the chemical analysis were previously kept in a $10 \%(\mathrm{v} / \mathrm{v}) \mathrm{HNO}_{3}$ solution for $24 \mathrm{~h}$ to avoid elemental contamination, and rinsed with deionized water prior to use.

For the cell culture, Dulbecco's Modified Eagle Medium with high glucose content (DMEM, Sigma, St. Louis, USA) was used. The medium was supplemented with $10 \%(\mathrm{v} / \mathrm{v})$ of inactivated fetal bovine serum (Cultilab, Campinas, Brazil) and $1 \%(\mathrm{v} / \mathrm{v})$ of antibiotic solution containing penicillin and streptomycin (Gibco ${ }^{\circledR}$, Carlsbad, USA). Phosphate buffer saline solution (PBS) and trypsin (2.5 g/L)-EDTA (0.2 g/L) solution were purchased from Cultilab.

Argon (99.996\%) was used in the ICP OES equipment and carbon dioxide $(99.5 \%)$ was used in the cells incubator, both acquired from White Martins (Campinas, Brazil).

\section{Instrumentation}

An inductively coupled plasma optical emission spectrometer (ICP OES, model Optima 8300, Perkin Elmer, Shelton, USA) was used for the determination of the elemental content of the samples. The operating parameters used are presented in Table I. 
Table 1: Operating parameters used for the determination of the elemental composition of samples of water, culture mediums and cells.

\begin{tabular}{|c|c|}
\hline Parameter & Value \\
\hline Power/W & 1400 \\
\hline Nebulizer gas flow rate/L $\min ^{-1}$ & 0,70 \\
\hline Auxiliary argon flow rate/L $\min ^{-1}$ & 0,5 \\
\hline Argon flow rate/L $\min ^{-1}$ & 15 \\
\hline Sample aspiration flow rate $/ \mathrm{mL} \mathrm{min}^{-1}$ & 1,0 \\
\hline Delay time/s & 45 \\
\hline Wavelength/nm & $\begin{array}{l}\text { Al: 308.215, Cr: 205.560; Co: } 228.616, \mathrm{Cu}: \\
\text { 324.752; Fe: 238.204, Mg: } 279.077, \mathrm{Mn}: \\
\text { 257.610, Mo: 202.031, Ni: 231.604, P: } \\
\text { 214.914, Pb: } 217.000, \mathrm{Zn}: 213.857\end{array}$ \\
\hline
\end{tabular}

In the treatment of the culture mediums and cells for the elemental analysis, a microwave digestion system (ETHOS1, Milestone, Sorisole, Italy) equipped with sensors for temperature and pressure control was used.

\section{Microwave-assisted acid digestion}

Aliquots of culture mediums $(5.0 \mathrm{~mL})$ and cells suspended in PBS (6.0 $\mathrm{mL})$ were placed inside the microwave vessels and $2.0 \mathrm{~mL}$ of $\mathrm{HNO}_{3}(65 \%$, w/w) and $1.0 \mathrm{~mL}$ of $\mathrm{H}_{2} \mathrm{O}_{2}(30 \%, \mathrm{w} / \mathrm{w})$ were added. The samples were then submitted to the following heating program:(1) heat from room temperature to $120^{\circ} \mathrm{C}$ in 5 min, (2) hold for $10 \mathrm{~min}$ at $120^{\circ} \mathrm{C}$, (3) heat from $120^{\circ} \mathrm{C}$ to $180^{\circ} \mathrm{C}$ in $5 \mathrm{~min}$, (4) hold for $15 \mathrm{~min}$ at $180^{\circ} \mathrm{C}$. The samples were left to cool, transferred to plastic flasks and the volume of the solutions was made up to $14.0 \mathrm{~mL}$ with deionized water.

\section{Cell culture}

The cell line Vero E6 (clone of kidney epithelial cells extracted from a kidney of African green monkey) was used as fibroblast model. The cells were cultivated using supplemented DMEM medium and kept in a controlled atmosphere composed by $95 \%$ of oxygen and $5 \%$ of carbon dioxide, in a humid environment and a temperature of $37^{\circ} \mathrm{C}$. The culture medium was changed 
every two days and the cells were monitored periodically by using a bio-inverted microscope (Nikon TS-100 - Japan). The cells were left to grow until, at least, $75 \%$ of confluence has been reached. Afterwards, the cells were washed with PBS and subsequently harvested using trypsin-EDTA solution. The cells were then re-suspended in the culture mediums prepared with the different types of water (thermal, deionized and tap) and plated in 24 wells-plates for the growth curve experiments and in culture flasks of $75 \mathrm{~cm}^{2}$ for the studies of the mineral composition.

The cell culture mediums were named as DECM, THCM and TACM, for the mediums prepared with deionized, thermal and tap water, respectively.

\section{Growth curve experiment and mineral composition}

For the growth curve, the cells were cultivated in 24 well-plates for 24, 48 and 76 hours, using the culture mediums prepared with the different types of water (thermal, deionized and tap). The cells were fixed with $4 \%(\mathrm{v} / \mathrm{v})$ paraformaldehyde and further washed with PBS and incubated for 20 min with DAPI (4',6-diamidino-2-phenylindole) at a final concentration of $150 \mathrm{ng} / \mathrm{mL}$, which produces a blue fluorescent label when bound to DNA. The cells were then observed with the aid of fluorescence microscopy (TS-100 Nikon ${ }^{\circledR}$ ). The cells number was quantified by using the Image ${ }^{\circledR}$ program and the graphics plotted in Origin ${ }^{\circledR}$ software.

For the studies of mineral composition, the cells were left to growth in the culture flasks until about of $100 \%$ of confluence. The cells were then washed with PBS and detached with trypsin-EDTA solution, centrifuged and resuspended in PBS. The number of cells in each flask was estimated by using a Neubauer Chamber.

\section{RESULTS AND DISCUSSION}

\section{Growth curve}

The results obtained for the growth curve are presented in Fig. 1 and a representation of cell populations in each stage is showed in Fig. 2. It was observed that the use of thermal water resulted in a higher cell viability with 48 $\mathrm{h}$ of cultivation. After 96 hours, it was observed no significant differences between the use of thermal and deionized water. On the other hand, cells 
cultivated with safe drinking water (tap water) showed a lower cell viability, which is probably related to the presence of other substances that could have affected the development of the cells in the studied conditions.

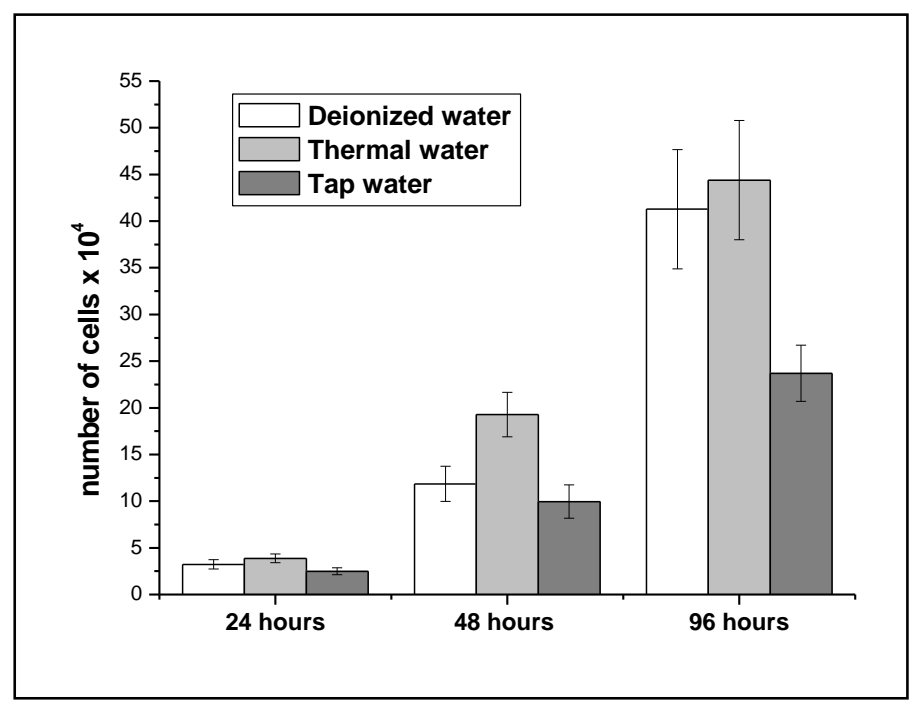

Figure 1: Growth curve of fibroblastic cells (Vero E6) cultivated with different

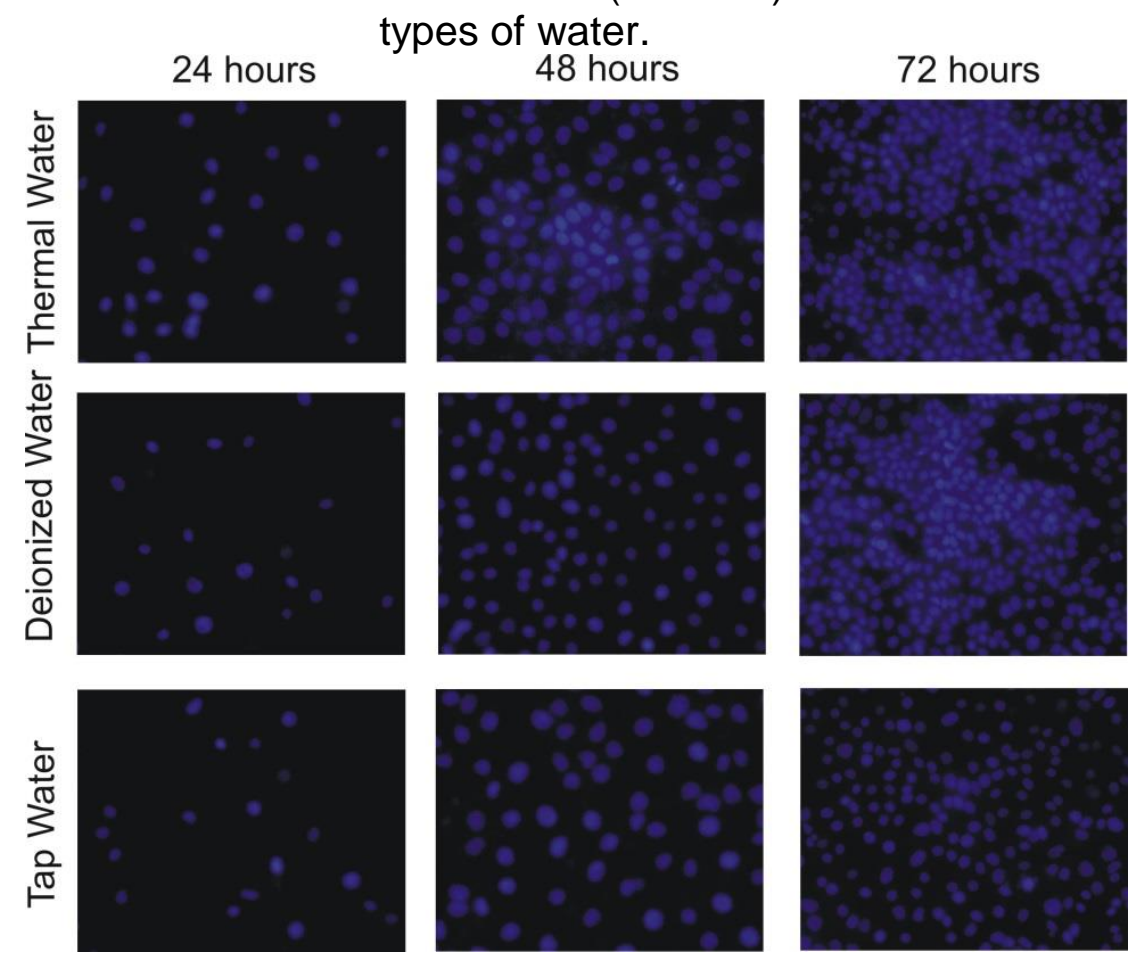

Figure 2: Representation of the growth curve of fibroblastic cells (Vero E6) cultivated with different types of water.

Nunes and Tamuka (2011) also did some in vitro studies to investigate the effects of the use of a Brazilian thermal water in cultures of fibroblastic cells. The results showed that this type of water presented no toxic and irritating effects for the cells and that thermal water stimulated the proliferation of 
fibroblasts, which is in agreement with the results found in this work (NUNES, TAMUKA, 2001)

The possible beneficial effects of the use of thermal water for the skin were also studied in other types of cells. Zöller et al. compared the effect of the use of thermal water with mineral water in cultures of keratinocytes (HaCaT) (ZÖLLER et al., 2015). In this case, thermal water suppressed cell proliferation and damage, but the studies showed a reduction on inflammatory processes when water from thermal springs was used, what was related to the presence of some essential elements in this type of water.

\section{Study of the mineral content}

The mineral composition of the samples of water used in the experiments, the culture mediums prepared with each type of water and the cells after cultivation were analyzed by ICP OES. The results obtained for the samples of water and their respective culture mediums are showed in Table II.

According to the concentrations described in Table II, thermal water presented significant amounts of $\mathrm{Ca}, \mathrm{K}, \mathrm{Na}$ and $\mathrm{Mg}$. Comparing the results obtained for thermal and tap water, thermal water presented lower concentrations of $\mathrm{Ca}$ and $\mathrm{Na}$, similar concentration of $\mathrm{K}$ and a higher concentration of $\mathrm{Mg}$ than tap water. The concentrations of $\mathrm{Mg}$ are particularly interesting, considering the essentiality of this element for the cells of the human body (COZZOLINO, 2007), where this element can be found mainly in the form of the ATP complex and phosphonucleotides, being directly involved in metabolic and bioenergetics processes (SIGEL, HELMUT, SIGEL, 2013). As expected, the deionized water presented very low concentrations of almost all elements, except for $\mathrm{Na}$.

As can be seen in Table II, the composition of culture mediums includes several essential elements for cellular functions such as $\mathrm{Ca}, \mathrm{K}, \mathrm{Na}, \mathrm{P}, \mathrm{Mg}$ and $\mathrm{Zn}$. Due to this, the contribution of the thermal water for increasing the elements concentrations were only significant for $\mathrm{Ca}$ and $\mathrm{Mg}$. The presence of other elements, such as $\mathrm{Mn}, \mathrm{Al}, \mathrm{Cr}, \mathrm{Cu}, \mathrm{Pb}, \mathrm{Mo}, \mathrm{Ni}$ and $\mathrm{Co}$, were also investigated in the samples of water and culture mediums, but for these elements, the concentrations were below the limits of detection (LOD) of the analytical method, as well as for some elements in the samples of water, as represented 
in Table II. In this case, it is important to point out that the ICP OES is usually employed for the determination of elements in concentrations of $\mathrm{mg} / \mathrm{L}$ (parts per million) and for these elements the concentrations are probably in $\mu \mathrm{g} / \mathrm{L}$ or lower, requiring the use of more sensitive analytical methods for their quantitation.

The mineral contents found in the cells cultivated with different types of water are represented in Fig 2. In Fig 2 a) the elements found in higher concentrations in the cells $(\mathrm{K}, \mathrm{Na}$ and $\mathrm{P})$ are represented while Figure $2 \mathrm{~b}$ ) represents the microelements ( $\mathrm{Mg}$ and $\mathrm{Zn}$ ).

According to the results, for all the elements that could be detected in the cells, the contents found were similar. The cells cultivated with the culture medium prepared with thermal water (THCM) were exposed to a higher $\mathrm{Mg}$ concentration. However, the greater concentration did not enhance the $\mathrm{Mg}$ uptake by the cells, indicating the intracellular $\mathrm{Mg}$ content is tightly regulated. In fact, mammalian cells regulate the $\mathrm{Mg}^{2+}$ cellular contents through several transport and buffering mechanisms to maintain the optimum activity of several enzymes and metabolic cycles in which magnesium is essential [34]. In this way, due to this well-regulated homeostasis processes the cells showed to be able to maintain the magnesium levels even when there was a lower $\mathrm{Mg}$ concentration in the extracellular environment, which is the case of the culture mediums prepared with deionized (DECM) and tap (TACM) water. In addition, the $\mathrm{Mg}$ concentrations found in the culture medium prepared with deionized water, which is the lower among the three culture mediums evaluated, is enough to maintain the cell functions and an excessive $\mathrm{Mg}$ amount, in a range low enough to not cause toxicity, had no effect in $\mathrm{Mg}$ intracellular contents. 
1 Table 2: Mineral contents ( $\mathrm{mg} / \mathrm{L}$ ) found in deionized, thermal and tap water and in the culture mediums prepared with each type of water.

\begin{tabular}{|c|c|c|c|c|c|c|}
\hline Element & Deionized & Thermal & Tap & DECM $^{1}$ & $\mathrm{THCM}^{2}$ & $\mathrm{TACM}^{3}$ \\
\hline $\mathbf{C a}$ & $<\mathrm{LOD}^{*}$ & $18.1 \pm 0.1$ & $33.70 \pm 0.02$ & $48 \pm 1$ & $58.1 \pm 0.2$ & $70.3 \pm 0.4$ \\
\hline K & $<$ LOD* & $2.59 \pm 0.03$ & $2.22 \pm 0.05$ & $291 \pm 1$ & $270 \pm 4$ & $286 \pm 3$ \\
\hline $\mathrm{Na}$ & $2.98 \pm 0.03$ & $10.92 \pm 0.04$ & $19.06 \pm 0.01$ & $3739 \pm 48$ & $3460 \pm 44$ & $3642 \pm 29$ \\
\hline $\mathbf{P}$ & $<\mathrm{LOD}^{*}$ & $<\mathrm{LOD}^{*}$ & $<\mathrm{LOD}^{*}$ & $20.33 \pm 0.06$ & $18.3 \pm 0.3$ & $18.6 \pm 0.3$ \\
\hline $\mathrm{Fe}$ & $<\mathrm{LOD}^{*}$ & $<\mathrm{LOD}^{*}$ & $<$ LOD* $^{*}$ & $<\mathrm{LOD}^{*}$ & $<$ LOD* $^{*}$ & $<$ LOD* $^{*}$ \\
\hline Mg & $<\mathrm{LOD}^{*}$ & $8.68 \pm 0.05$ & $4.46 \pm 0.01$ & $12.87 \pm 0.07$ & $17.0 \pm 0.1$ & $15.4 \pm 0.3$ \\
\hline $\mathbf{Z n}$ & $<$ LOD* & $<$ LOD* & $<\mathrm{LOD}^{*}$ & $0.02 \pm 0.01$ & $0.04 \pm 0.02$ & $0.06 \pm 0.02$ \\
\hline
\end{tabular}

$2{ }^{1}$ DECM: culture medium prepared with deionized water, ${ }^{2} \mathrm{THCM}$ : culture medium prepared with thermal water, ${ }^{3} \mathrm{TACM}$ : culture medium

3 prepared with tap water.

$4{ }^{*}<$ LOD $=$ the concentrations are lower the limits of detection (LOD) of the analytical method. 


\section{FINAL CONSIDERATIONS}

Cells cultivated with thermal water exhibited a higher and a similar growth rate than cells cultivated with deionized water with 48 and 76 hours of culture, respectively, showing that the use of this type of water can contribute for the renovation of skin cells.

According to the mineral content analysis, thermal water presents high levels of $\mathrm{Ca}, \mathrm{Na}$ and $\mathrm{Mg}$. However, the contribution of these elements to the mineral contents of the different culture mediums was only significant for $\mathrm{Mg}$, due to the higher levels of this element found in thermal water. In this way, cells cultivated employing thermal water were exposed to a higher Mg concentration, but the higher contents did not enhance the uptake of this element by the cells due to homeostasis processes that tightly regulate the $\mathrm{Mg}$ intracellular contents.

\section{ACKNOWLEDGEMENTS}

The authors acknowledge the Fundação de Amparo à Pesquisa do Estado de São Paulo, the Conselho Nacional de Desenvolvimento Científico e Tecnológico (Cnpq) and INCTAA (Instituto de Nacional de Ciências e Tecnologias Analíticas Avançadas) for financial support.

\section{REFERENCES}

BARATA E. Cosméticos - Arte e Ciência. Lisboa, Libel; 2002.

BERNSTEIN, E.F.; UNDERHILL, C.B.; HAHN, P.J., BROWN, D.B.; UITTO, J. Chronic sun exposure alters both the content and distribution of dermal glycosaminoglycans. Br. J.

Dermatol. 1996, 135(2): 255-262.

BOCK M,; SCHURER, N.Y.; SCHWANITZ, H.J. Effects of $\mathrm{CO}_{2}$-enriched water on barrier recovery. Arch. Dermatol. Res. 2004, 296(4): 163-168.

CHEBASSIER, N; OUIJJA, E.H.; VIEGAS, I.; DRENO, B. Stimulatory effect of boron and manganese salts on keratinocyte migration. Acta Derm. Venereol. 2004, 84(3): 191-194.

COZZOLINO, S.M.F.. "Biodisponibilidade de nutrientes", Manole; 2007.

CUNHA, A.; SILVA ROQUE, O; CUNHA E. Plantas e produtos Vegetais em Cosmética e Dermatologia. Lisboa, fundação Colouste Gulbenkian; 2004.

DRAELOS, Z.D.; ERTEL, K.D.; BERGE, C.A. Facilitating facial retinization through barrier improvement. Cutis. 2006, 78(4): 275-281.

ELKHYAT, A; COURDEROT-MASUYER C; MAC-MARY, S.; COURAU, S.; GHARBI, T.; HUMBERT, P. Assessment of spray application of Saint Gervais water effects on skin 
wettability by contact angle measurement acomparison with bidistilled water. Skin Res. Technol. 2004, 10(4): 283-286.

FAÍLDE, R.M.; MOSQUEIRA, L.M. Afecciones dermatológicas y cosmetic dermotermal. In: Técnicas y Tecnologias en hidrologia Médica e Hidroterapia. Ag. Eval. Tec. Sanitarias AETS. 2006, 50(1):175-194.

GHERSETICH, I; BRAZZINI, B.; HERCOGOVA, J; LOTTI T. Mineral Waters: Instead of Cosmetics or Better than Cosmetics? Clin. in Dermatol. 2001, 19(4): 478-482.

GOMES, C.S.F.; SILVA, J.B.P.. Mineral and clay mineral in medical geology. App. Clay Sci. 2007, 36(1): 4-21.

HALEVY, S.; SUKENIK, S. Different modalities of spa therapy for skin diseases at the dead sea area. Arch. Dermatol. 1998, 134(11): 1416-1420.

HALLIDAY, G.M.; NORVAL, M; BYRNE, S.N.; HUANG, X.X.; WOLF, P. The effects of sunlight on the skin. D. Discov. Today: Dis. Mechan. 2008, 5(2): 201-209.

HASHIZUME, H. Skin aging and dry skin. J. Dermatol. 2004, 31(8): 603-609.

LAQUIEZE, S.; CZERNIELEWSKI, J.; BALTAS E. Beneficial use of Cetaphil moisturizing cream as part of a daily skin care regimen for individuals with rosacea. J. Dermatolog. Treat. 2007, 18(3): 158-162.

LOTTI, T. and GHERSETICH, I. Mineral Waters: Instead of soap or Better than soap? Clin. in Dermatol. 1996, 14(1): 101-104.

MATZ, H; ORION, E,; WOLF, R. Balneotherapy in dermatology. Dermatol. Ther. 2003, 16(2): 132-140.

NAKAGAWA, N.; SAKAI, S; MATSUMOTO, M.; YAMADA, K.; NAGANO, M.; YUKI, T, et al. Relationship between NMF (lactate and potassium) content and the physical properties of the stratum corneum in healthy subjects. J. Invest. Dermatol. 2004,122(3): 755-763.

NOCCO, P.B. Mineral water as a cure. Veroff. Schweiz. Ges. Gesch. Pharm. 2008; 29:13402.

NUNES, S.; TAMRA, B.M. Avaliação bioquímica e toxicológica de uma água mineral brasileira e seus efeitos cutâneos em uso tópico. Surg. Cosmet. Dermatol. 2011, 3(3): 197-202.

POENSIN, D; CARPENTIER, P.H.; FÉCHOZ, C.; GASPARINI, S. Effects of mud pack treatment on skin microcirculation. Joint Bone Spine. 2003, 70(5): 367-370.

PRISTA, L.; BAHIA, M.; VILAR, E. Dermofarmácia e Cosmética. Porto, Associação Nacional das Farmácias; 1992.

RAWLINGS, A.V.; HARDING, C.R.. Moisturization and skin barrier function. Dermatol. Ther. 2004, 17(1): 43-48.

ROQUES, C.F.; DE BOISSEZON, X.; QUENEAU, P. Crenobalneotherapy: a medical and scientific update. Bull Acad. Natl. Med. 2009, 193(5): 1165-1180.

SALMON, J.K.; ARMSTRONG, C.A.; ANSEL, J.C. The skin as an immune organ. West J. Med. 1994, 160(2): 146-152 
SEITE, S. Thermal waters as cosmeceuticals: La Roche-Posay thermal spring water example. Clin. Cosm. Investig. Dermatol. 2013, 6: 23-28.

SIGEL A.; HELMUT, S.; SIGEL, R.K.O. ed. interrelations between Essential Metal lons and Human Diseases", Springer, Dordrecht. 2013.

SUMMA, V.; TATEO, F. The use of pelitic raw materials in thermal centres: mineralogy, geochemistry, grain size and leaching test. Examples from Lucania area (Southern Italy). Appl. Clay Scie. 1998, 12(5): 403-417.

TEIXEIRA, F. Diaporama de Hidrologia Médica - Doapositivos do Curso de Pós graduação em termalismo da Universidade de Beira Interior (UBI); 2007.

VILE, G.F.; TYRRELL, R.M. UVA radiation-induced oxidative damage to lipids and proteins in vitro and in human skin fibroblasts in dependent on iron and singlet oxygen. Free Radic. Biol. Med. 1995, 18(4): 721-730.

WILHELM, K.P.; FREITAG, G.; WOLFF, H.H. Surfactant-induced skin irritation and skin repair. Evaluation of the acute human irritation model by noninvasive techniques. J. Am. Acad.

Dermatol. 1994, 31(4): 944-949.

WILLIAMS, S.; KRUEGER, N.; DAVIDS, M.; KRAUS, D.; KERSCHER, M.M. Effect of Fluid intake on skin physiology: distinct differences between drinking mineral water ant tap water. Int. J. Cosmet. Sci. 2007, 29(2): 131-138.

YURTKURAN, M.; YURTKURAN, M.; ALP, A.; NASIRCILAR BINGÖL, Ü.; ALTAN, L.; SARPDERE, G. Balneotherapy and tap water therapy in treatment ok knee osteoarthritis.

Rheumatol. Int. 2006, 27(1): 19-27.

ZÖLLER, N.; VALESKY, E.; HOFMANN, M.; BEREITER-HAHN, J.;BERND, A.; KAUFMANN, R.; MAISSNER, M., et al. Impact of different spa waters on inflammation parameters in human keratinocyte HaCaT cells. Ann. Dermatol. 2015, 27(6): 709-714. 